\title{
SISTEM INFORMASI AKUNTANSI ARUS KAS PADA DINAS PERHUBUNGAN KABUPATEN KENDAL MENGGUNAKAN METODE ACCRUAL BASIS
}

\author{
Munifah $^{1}$, Edy Siswanto ${ }^{2}$, Tedy Wahyu Pramuditya ${ }^{3}$ \\ Universitas Sains dan Teknologi Komputer \\ Semarang, Indonesia \\ Email: munifah@stekom.ac.id, edy@stekom.ac.id,tedywahyu98@gmail.com
}

\begin{abstract}
The financial recording system at the Kendal Department of Transportation is still using a manual system, meaning that all transaction activities that occur are only written in bookkeeping, and do not yet have a special application used in data processing and financial reporting. Prone to cause loss of transaction data thus hampering the reporting process. In addition, it is difficult to find financial data on cash receipts and disbursements due to the unavailability of an accessible web-based financial information system. The Kendal Regency Transportation Office needs an application that can be used in data processing and financial statement presentation and displays financial reports quickly, effectively and efficiently when needed and makes it easier to obtain financial information at the Kendal Regency Transportation Office. The application of a cash flow accounting information system at the Kendal Regency Transportation Office has achieved the desired goal, namely to simplify the process of recording cash financial transactions so that the use of cash management time is more efficient and presents financial reports of income, expenses and cash flows quickly, precisely and accurately.
\end{abstract}

Keyword: System, Information, Accounting, Cash Flow, Finance, Accrual Basis

\section{PENDAHULUAN}

Kas merupakan alat pembayaran yang dibutuhkan perusahaan dalam mengelola bisnisnya. Kegunaan kas dalam perusahaan sebagai dana kegiatan operasional perusahaan sehari-hari. Kas memerlukan perhatian khusus karena kas merupakan hal penting dalam kelangsungan hidup perusahaan. Pemprosesan kas yang tidak efektif akan menyebabkan kas yang berlebihan. Manajemen harus mengendalikan penggunaan kas, terutama kas yang mengendap yang tidak dimanfaatkan untuk melakukan aktivitas normal perusahaan, hal ini diperlukan untuk menghindari resiko tidak tercapainya realisasi (Maryono, 2017).

Perusahaan harus menyusun anggaran perusahaan untuk menghitung perbandingan total kas yang dibutuhkan dan tujuannya. Tujuan utama anggaran kas adalah untuk dapat menjalankan kegiatan perusahaan serta menjaga atau 
menghindari gangguan likuiditas perusahaan. Kas adalah aset yang paling likuid yang memiliki peranan yang sangat besar dalam pengoperasian aktivitas organisasi. Secara langsung maupun tidak langsung hal tersebut akan berpengaruh pada aktivitas keuangan perusahaan.

Pada era globalisasi yang semakin berkembang, teknologi informasi juga berkembang dengan pesat. Sehingga kegiatan berjalan efektif dan efisien untuk mencapai tujuan perusahaan secara maksimal. Dengan menggunakan teknologi informasi yang berbasis web, kantor dinas dapat memperoleh informasi dengan tepat, cepat, serta akurat yang dapat digunakan untuk pengambilan keputusan penerimaan dan pengeluaran di mana saja dan kapan saja.

Ada dua metode untuk pencatatan transaksi dalam akuntansi yaitu metode basis akrual dan metode basis kas. Basis kas merupakan teknik pencatatan pada saat terjadinya transaksi dimana kas tersebut betul-betul dikeluarkan maupun diterima. Sedangkan basis akrual merupakan metode akuntansi dimana pengeluaran dan penerimaan dicatat dan diakui pada saat terjadinya transaksi (Halim dan Kusufi, 2014). Hal terpenting yaitu pada saat transaksi terjadi langsung dicatat, karena transaksi tersebut memiliki implikasi uang masuk atau keluar dimasa depan.

Sistem pencatatan keuangan di Dinas Perhubungan Kendal selama ini masih menggunakan sistem manual, artinya semua kegiatan transaksi yang terjadi hanya ditulis pada buku pembukuan, dan belum memiliki aplikasi khusus yang digunakan dalam pemprosesan data dan pembuatan laporan keuangan. Rawan menimbulkan kehilangan data-data transaksi sehingga menghambat proses pembuatan laporan. Selain itu kesulitan dalam pencarian data-data keuangan penerimaan dan pengeluaran kas karena belum memiliki sistem informasi keuangan yang dapat diakses.

Selain itu kesulitan dalam pencarian data-data keuangan penerimaan dan pengeluaran kas karena belum adanya sistem informasi keuangan berbasis web yang dapat diakses. Dibawah ini data penerimaan dan pengeluaran di Dinas Perhubungan Kabupaten Kendal selama tahun 2016-2018, sebagai berikut: 
Tabel 1. Penerimaan dan pengeluaran Dinas Perhubungan Kab. Kendal Pada Tahun 2017 - 2019

\begin{tabular}{cccc}
\hline No & Tahun & Penerimaan & Pengeluaran \\
\hline 1. & 2017 & 133.080 .000 & 66.920 .000 \\
2. & 2018 & 156.969 .000 & 43.031 .000 \\
3. & 2019 & 157.965 .000 & 42.035 .000 \\
\hline
\end{tabular}

(Sumber : Dinas Perhubungan Kab. Kendal, 2020)

Dari tabel diatas diketahui bahwa penerimaan dan pengeluaran dari periode ke periode mengalami peningkatan yang tadinya tahun 2017 penerimaannya $\mathrm{Rp}$. 133.080.000 untuk tahun 2019 menjadi Rp. 157.965.000 dan pengeluaran mengalami penurunan dari tahun 2017 Rp. 66.920.000 menjadi Rp. 42.035.000.

Berdasakan permasalahan yang diuraikan diatas, penulis melakukan penelitian mengenai Sistem informasi akuntansi arus kas di Dinas Perhubungan Kabupaten Kendal menggunakan metode accrual basis guna menciptakan sebuah aplikasi yang dapat membantu dalam pemprosesan data dan penyajian laporan keuangan yang menghasilkan dan menampilkan laporanlaporan keuangan dengan cepat, efektif dan efisien pada saat dibutuhkan dan memudahkan dalam memperoleh informasi keuangan pada Dinas Perhubungan Kabupaten Kendal.

\section{METODE PENELITIAN}

Penelitian ini, prosedur pengembangannya menggunakan metode $\mathrm{RnD}$, tujuan dari langkah-langkah $\mathrm{RnD}$ adalah memperoleh sebuah produk yang efektif dan desain sistem yang valid serta memiliki nilai guna lebih dari sistem yang lama.

Model pengembangan $\mathrm{RnD}$ yang digunakan untuk menghasilkan produk tertentu serta menguji keefektifan produk tersebut, beberapa tahapan yaitu : 


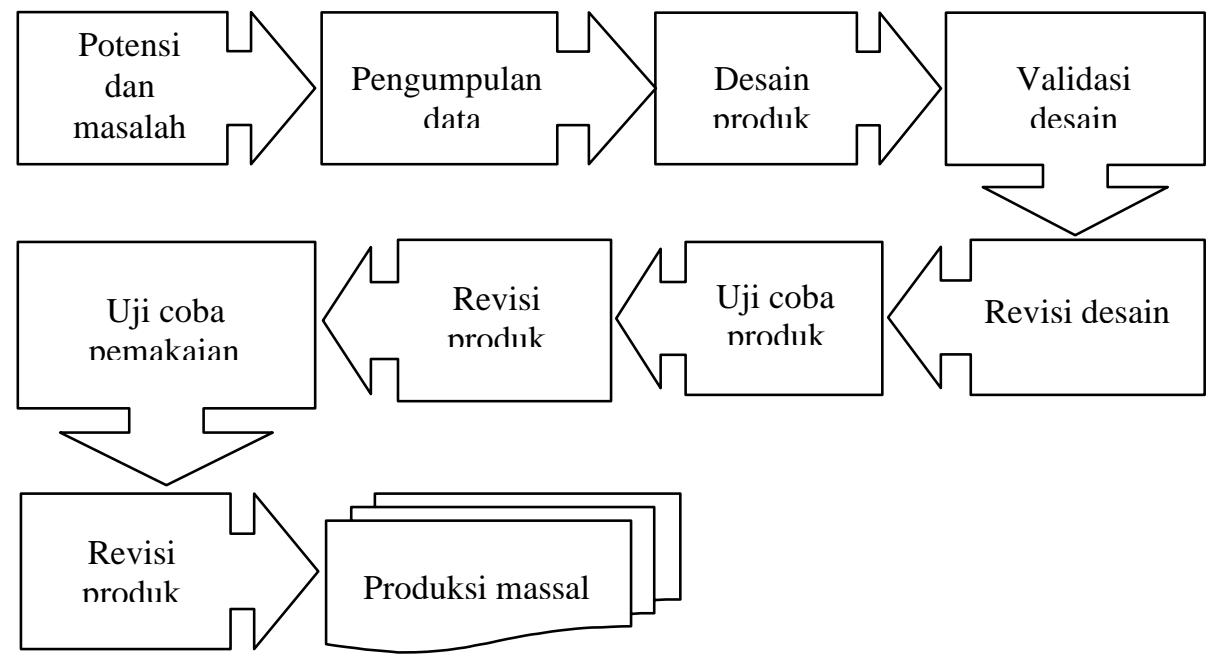

Gambar 1. Model Pengembangan Research and Development.

(Sugiyono, 2016)

\subsection{Prosedur Pengembangan}

Prosedur pengembangan sistem informasi akuntansi arus kas dapat digambarkan sebagai berikut :

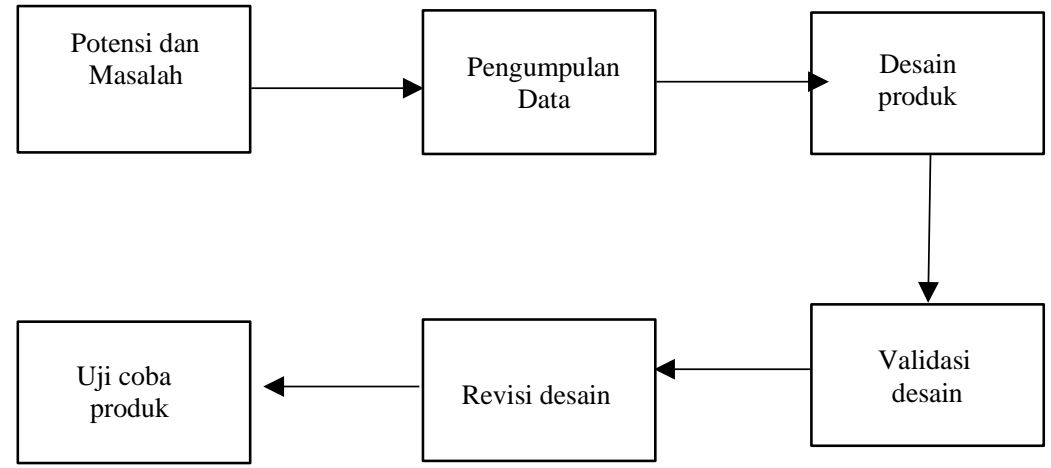

Gambar 2. Prosedur Pengembangan

Langkah-langkah diatas adalah :

1. Potensi dan masalah

Adapun masalah yang dihadapi oleh Dinas Perhubungan Kendal adalah pencatatan keuangan kas masih menggunakan sistem manual, yaitu aktifitas yang dilakukan hanya ditulis di buku pembukuan penerimaan dan pengeluaran, hal tersebut seringkali menimbulkan kehilangan data-data transaksi sehingga menghambat proses pembuatan laporan. Selain itu kesulitan dalam pencarian data-data keuangan penerimaan dan pengeluaran kas karena belum tersedianya sistem 
informasi keuangan berbasis web yang dapat diakses.

2. Pengumpulan data

Tahap ini penulis mengumpulkan beberapa data-data dan informasi yang dibutuhkan caranya dengan: Metode wawancara, metode observasi dan metode studi pustaka.

3. Desain produk

Pengembangan desain produk dengan cara membuat perancangan sistem yaitu flowchart, DFD, ERD, dan perancangan user interface, dan arsitektural sistem.

4. Validasi desain

Melakukan evaluasi setelah desain prouk selesai dibuat yang dilakukan oleh pakar yang berkompeten dengan menggunakan bahasa pemrograman PHP dan database MySql. langkah ini ditunjukan untuk menilai kesesuaian desain produk dengan tujuan penelitian, jika ada kekurangan dan kesalahan, maka harus dilakukan perbaikan.

5. Revisi desain

Pada langkah berikutnya dilakukan perbaikan terhadap kekurangan dan kesalahan pada sistem yang ada, serta menambah komponenkomponen dari masukan-masukan validator, untuk menyempurnakan produk yang kemudian di ujikan kembali kepada validator.

6. Uji coba produk

Tahap terakhir dilakukan uji coba pada model evaluasi beserta perangkat modelnya dan instrumen yang digunakan untuk mengetahui sampai mana model evaluasi beserta perangkat model dan instrumen tersebut dapat digunakan di Dinas Perhubungan Kendal. Hasil uji coba dianalisis untuk dapat diketahui kelayakan dari model tersebut. Hasil tersebut akan direvisi dan diuji cobakan lagi jika belum memenuhi persyaratan fit model.

\section{HASIL \& PEMBAHASAN}

\subsection{Perancangan Sistem}

Sistem yang dibuat merupakan usulan perancangan sistem 
untuk memperbaiki dan mengembangkan sistem yang sedang berjalan saat ini. Sistem ini memiliki peranan penting dalam menyediakan informasi dan penyajian laporan arus kas.

Sebelum merancang Sistem informasi akuntansi arus kas pada Dinas Perhubungan Kabupaten Kendal menggunakan metode accrual basis penulis merancang desain flowchart, normalisasi, ERD, DFD, database MySQL, dan desain uji coba program.

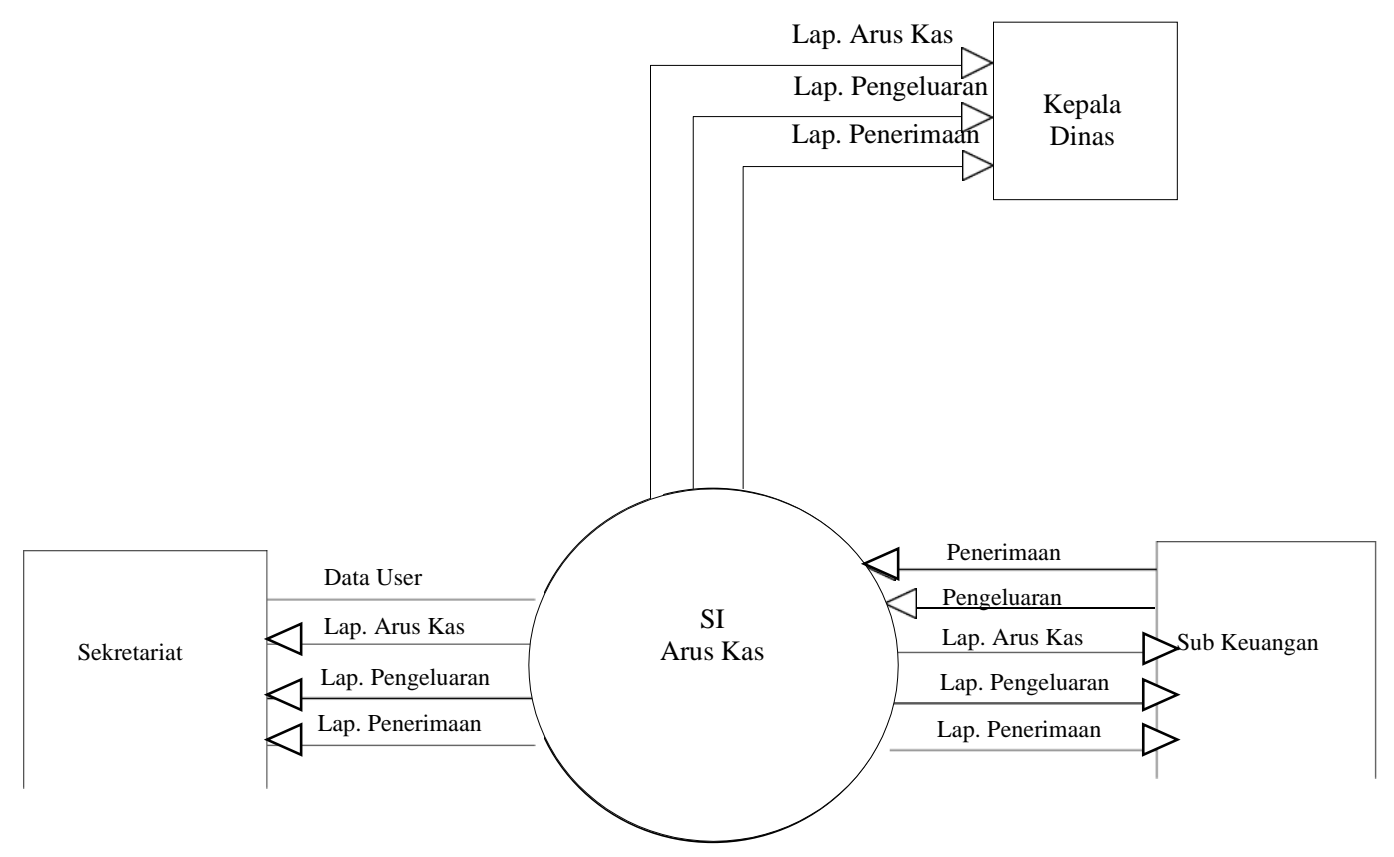

Gambar 3. Context Diagram Sistem Informasi Arus Kas

\subsection{Pembahasan Produk Akhir}

Berikut merupakan tampilan dari aplikasi Sistem informasi akuntansi arus kas pada Dinas Perhubungan Kabupaten Kendal menggunakan metode accrual basis.

\subsubsection{Form Login}

Berikut adalah login ke menu utama : 


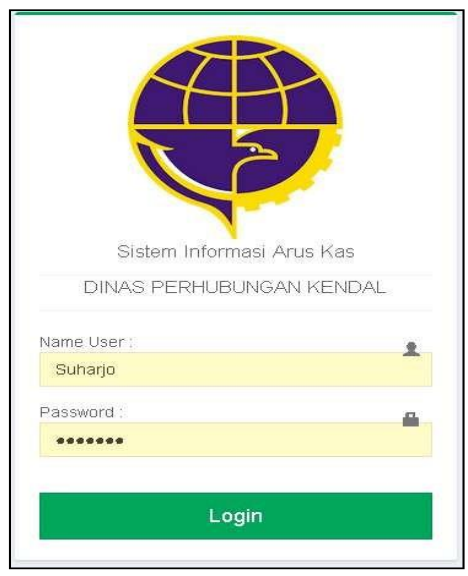

Gambar 4. Tampilan Form Login

\subsubsection{Menu Utama}

Tampilan menu utama digunakan user Sekretariat :

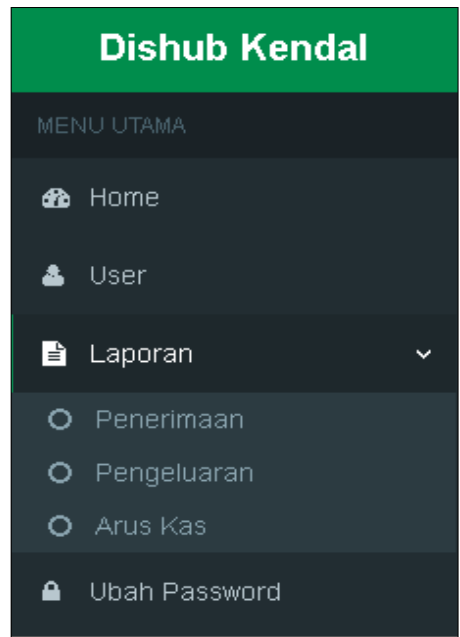

Gambar 5. Tampilan Menu Utama User Sekretariat

Berikut adalah Tampilan menu utama digunakan user Sub Keuangan:

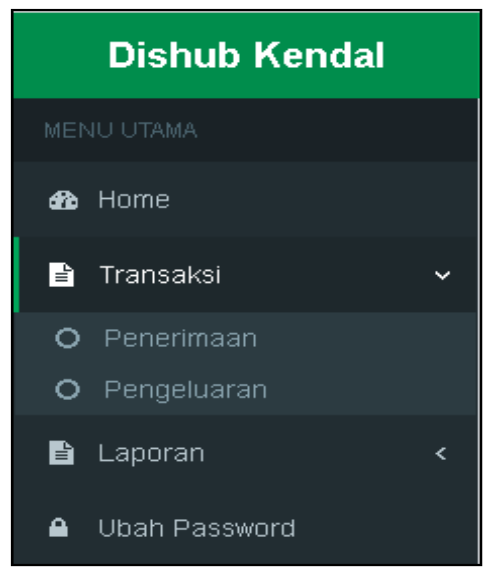

Gambar 6. Tampilan Menu Utama User Sub Keuangan 
Berikut adalah Tampilan menu utama digunakan $u s e r$ Kepala Dinas:

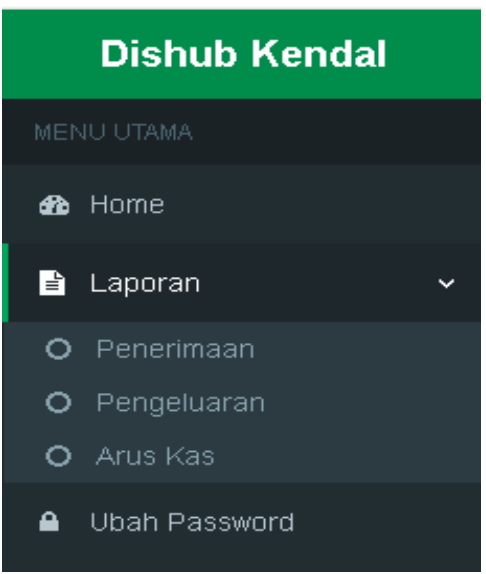

Gambar 7. Tampilan Menu Utama User Kepala Dinas

\subsubsection{Form User}

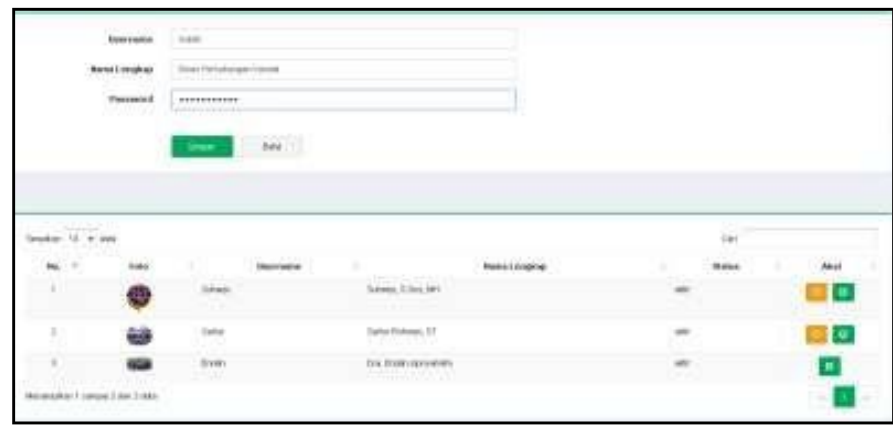

Berikut adalah tampilan Form User:

Gambar 8. Tampilan Form User

\subsubsection{Form Penerimaan}

Berikut adalah tampilan Form Penerimaan :

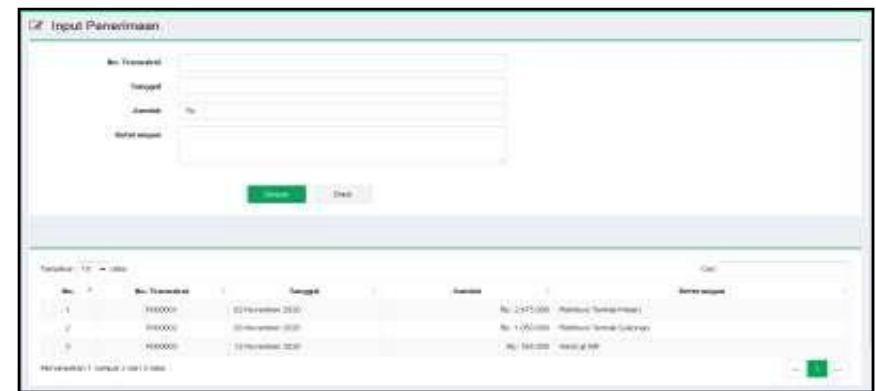

Gambar 9. Tampilan Form Penerimaan 


\subsubsection{Form Pengeluaran}

Berikut adalah tampilan Form Pengeluaran :

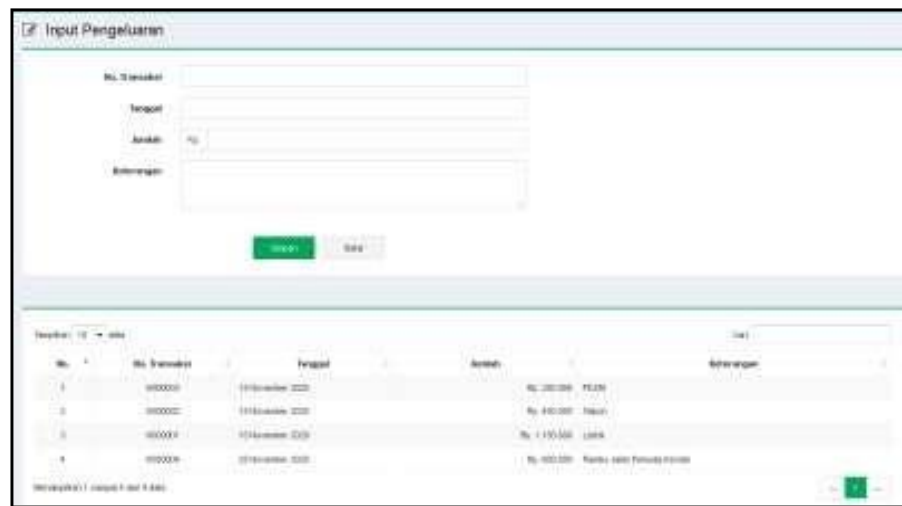

Gambar 10. Tampilan Form Pengeluaran

\subsubsection{Laporan Penerimaan}

Berikut adalah tampilan Laporan Penerimaan :

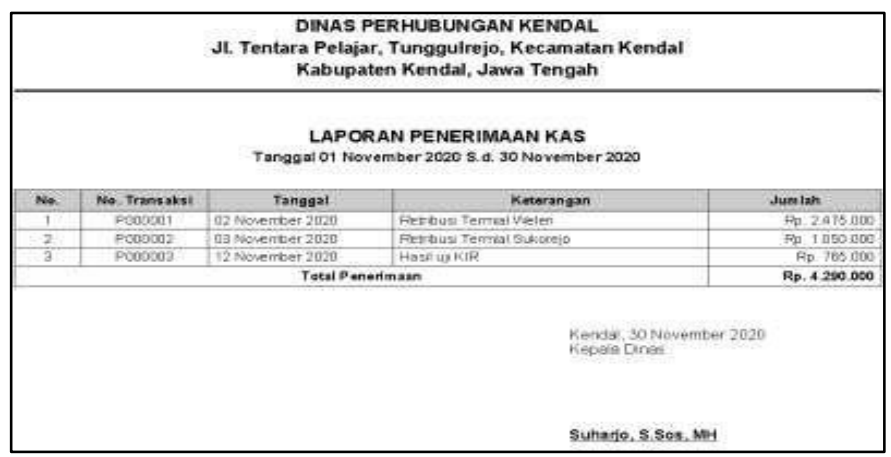

Gambar 11. Laporan Penerimaan

\subsubsection{Laporan Pengeluaran}

Berikut adalah tampilan Laporan Pengeluaran :

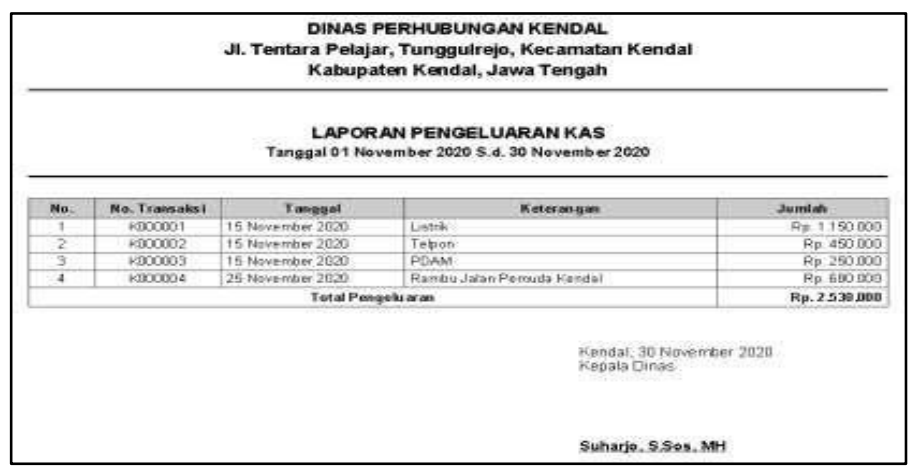

Gambar 12. Laporan Pengeluaran 


\subsubsection{Laporan Arus Kas}

Tampilan Laporan Arus Kas :

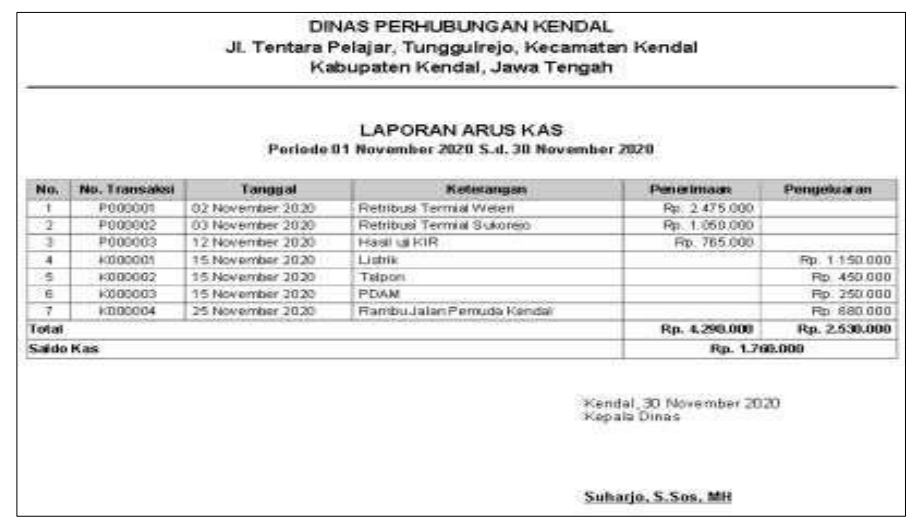

Gambar 13. Laporan Arus Kas

\section{KESIMPULAN}

Dari penelitian diatas dapat disimpulkan yaitu :

1. Pembuatan sistem informasi akuntansi arus kas pada Dinas Perhubungan Kabupaten Kendal menggunakan metode accrual mempermudah dalam proses pencatatan transaksi keuangan kas sehingga penggunaan waktu pengeloaan kas lebih efisien.

2. Pembuatan sistem informasi akuntansi arus kas pada Dinas Perhubungan Kabupaten Kendal dapat menyajikan laporan keuangan pendapatan, pengeluaran dan arus kas dengan tepat, cepat dan akurat.

\section{REFERENSI}

Halim, A., \& Kusufi, M. S (2014). Akuntasi Sektor Publik, Akuntansi Keuangan Daerah. Jakarta: Salemba Empat.

Maryono (2017) Perancangan Aplikasi Laporan Arus Kas Web pada Dinas Perhubungan Kota Sukabumi.

Sugiyono (2016) Metode Penelitian Kuantitatif, Kualitatif dan R\&D. Bandung : Alfabeta 